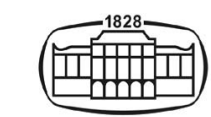

AKADÉMIAI KIADÓ

\title{
Evaluation of cell-penetrating peptide-peptide nucleic acid effect in the inhibition of cagA in Helicobacter pylori
}

\section{Acta Microbiologica et Immunologica Hungarica 67 (2020) 1, 66-72}

DOI: $10.1556 / 030.66 .2019 .032$ (c) 2019 Akadémiai Kiadó, Budapest

\section{ORIGINAL ARTICLE}

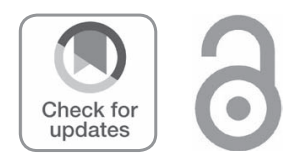

\author{
ZAHRA JAVANMARD ${ }^{1,2}$, BEHROOZ SADEGHI KALANI ${ }^{3}$, \\ SHABNAM RAZAVI ${ }^{1,2}$, NARGES NODEH FARAHANI ${ }^{1,2}$, \\ ROKHSAREH MOHAMMADZADEH ${ }^{2}$, \\ FATEMEH JAVANMARD $^{4}$ and GHOLAMREZA IRAJIAN ${ }^{1,2 *}$
}

\footnotetext{
${ }^{1}$ Microbial Biotechnology Research Center, Iran University of Medical Sciences, Tehran, Iran

${ }^{2}$ Department of Microbiology, School of Medicine, Iran University of Medical Sciences, Tehran, Iran

${ }^{3}$ Clinical Microbiology Research Center, Ilam University of Medical Sciences, Ilam, Iran

${ }^{4}$ Department of Laboratory Sciences, Qom University of Mdical Sciences and Health Services, Qom, Iran
}

Received: November 30, 2018 • Accepted: May 15, 2019 • Published online: February 11, 2020

\begin{abstract}
Helicobacter pylori is the most common cause of chronic infection in human and is associated with gastritis, peptic ulcer disease, and adenocarcinoma of mucosa-associated lymphoid tissue cells. Peptide nucleic acid (PNA) is a synthetic compound, which can inhibit the production of a particular gene. This study aimed to investigate the effect of PNA on inhibiting the expression of cagA. After confirmation of the desired gene by polymerase chain reaction (PCR), the antisense sequence was designed against cagA gene. The minimum inhibitory concentrations of conjugated PNA against $H$. pylori was determined. The effect of the compound on the expression level of the cagA was investigated in HT29 cell culture using real-time PCR. The results showed 2 and $3 \log$ reduction in bacterial count after 8-and 24-h treatment with 4 and $8 \mu \mathrm{M}$ of the compound, respectively. The lowest expression level of the cagA gene was observed at a concentration of $8 \mu \mathrm{M}$ after $6 \mathrm{~h}$. The results of this study showed that cell-penetrating peptide antisense can be employed as effective tools for inhibiting the target gene mRNA for various purposes. Moreover, further research is necessary to assess the potency, safety, and pharmacokinetics of CPP-PNAs for clinical prevention and treatment of infections due to H. pylori.
\end{abstract}

\section{KEYWORDS}

Helicobacter pylori, peptide nucleic acid, antisense, real-time PCR, cell culture

\section{INTRODUCTION}

Gastric cancer is the third most common cause of cancer death in the world. Multiple epidemiological studies have documented an increasing incidence of gastric cancer with an increasing prevalence of Helicobacter pylori infection [1-4]. In 1994, the International Agency for Research on Cancer, World Health Organization (WHO), classified H. pylori as a group I carcinogen, a definite cause of cancer in humans. Additional large-scale prospective cohort studies confirmed the association between $H$. pylori infection and gastric cancer [5-8]. It is now well accepted that $H$. pylori is the single greatest risk factor for the development of gastric cancer, accounting for about $75 \%$ of all gastric cancers [9]. This microorganism is estimated to infect approximately half of the entire human population and is the most frequently occurring chronic bacterial infection in developing countries [10]. Moreover, the colonization of $H$. pylori as a bacterial pathogen in the stomach can cause a number of gastric diseases, such as peptic ulcers, chronic gastritis, and mucosa-associated lymphoid tissue (MALT) lymphoma $[11,12]$.

\footnotetext{
* Corresponding author: Gholamreza Irajian, PhD Department of Medical Microbiology, School of Medicine, Iran University of Medical Sciences, Tehran, Iran Fax: +98 2188058649 E-mail: dr.irajian@gmail.com 
H. pylori infection is primarily acquired during childhood and the transmission occurs through an oral-oral or fecaloral route within families, particularly in the settings with poor sanitation. In the majority of cases, the colonized H. pylori persists in the stomach over the lifetime of the host unless eradicated with antibiotics [13].

In general, bacterial pathogenic factors can be divided into the factors related to colonization and factors responsible for tissue damage. Cytotoxin-associated gene $\mathrm{A}$ (cagA) and vacuolating cytotoxin $\mathrm{A}$ (vacA) are the main factors associated with $H$. pylori pathogenesis [14-18].

CagA is a surface protein with a high immune function, which is activated after penetrating gastric epithelial cells and phosphorylation. This can lead to many functional and morphological changes within the host gut cells, including apoptosis of host cells and interfering with cell signaling leading to the pathogenicity of the bacteria and the expression of the genes of cag pathogenicity islands (cag PAI) [16, 19, 20].

The presence of the cagA gene is associated with the development of diseases, such as duodenal ulcer, mucosal atrophy, and gastric cancer. Strains containing the cagA gene are more likely to be associated with apoptosis in adenocarcinoma gastric cells [21]. Initial research on 21 different species of $H$. pylori proves the relationship between the presence of cagA and the potentiality of multiple morphological and biochemical changes in human stomach cells.

Today, the treatment of $H$. pylori infection is facing serious challenges due to the emergence of antibacterial resistance. Researchers now argue that antibiotics alone are not enough to fight with bacteria, and there is a pressing need for new compounds. Suppressing essential virulence genes or inhibiting mRNA genes using antisense mechanisms can be considered as an interesting solution. Peptide nucleic acid (PNA) is a synthetic compound consisting of a pseudopeptide structure and a target gene complement that results in inhibitory transcriptional contractions and thus inhibition of translation as well as the affinity and specificity of these compounds in binding target genes have been proven [19-21]. PNA molecules are in fact synthetic DNA mimics with a neutrally charged chemical backbone with a higher affinity for DNA or RNA complementary sequences $[22,23]$. PNA molecules that are more resistant to nucleases and proteases are usually about 13-18 bp, with the ability to penetrate the bacterial cell wall [22].

The negatively charged sugar-phosphate backbone of PNA molecules is replaced by an achiral, neutral polyamide backbone formed by repetitive units of $\mathrm{N}$-(2-aminoethyl) glycine $[17,18]$. PNA can hybridize with complementary nucleic acid targets according to the Watson-Crick basepairing model [7].

The most important challenge in using the antisense compound as a drug has been the limitation of the penetration of bacterial cell membranes due to its selective permeability. Today, using the process of conjugating cell-penetrating peptides (CPPs) to the antisense compound as a transitional system has removed this restriction $[24,25]$.

Considering the importance of this bacterium and the emergence of antibiotic resistance, the aim of this study was to design antisense and intrusive peptide sequences to inhibit cagA virulence gene in the laboratory environment and cell culture in $H$. pylori bacteria.

\section{MATERIALS AND METHODS}

\section{Bacterial strain}

H. pylori standard strain (ATCC 43504) was used in this study. H. pylori strain was grown on blood agar media (43 g Columbia blood agar base (Acumedia, Svenska Labfas, Ljusne, Sweden), DL-tryptophan $(0.1 \mathrm{~g})$, deionised water $(1 \mathrm{~L})$, and horse blood $(60 \mathrm{ml})$ in a humidified microaerobic environment (nitrogen $85 \% \mathrm{v} / \mathrm{v}$, carbon dioxide $10 \% \mathrm{v} / \mathrm{v}$, and oxygen $5 \% \mathrm{v} / \mathrm{v}$ ) at $35{ }^{\circ} \mathrm{C}$ for 3 days.

\section{Primer design}

The sequences of primers in this study were designed by Oligo 7 [26] and Primer 3 software [27] (Table I).

\section{DNA extraction}

Genomic DNA from each isolate was prepared by vortex after suspending a loopful of colonies in $1 \mathrm{ml}$ of phosphated-buffer saline, centrifuging at $14,000 \times g$ for $2 \mathrm{~min}$, and boiling the pellet in $1 \mathrm{ml}$ of distilled water for $1 \mathrm{~min}$ [28]. The samples were then centrifuged at $12,000 \times g$ for $4 \mathrm{~min}$ at $4{ }^{\circ} \mathrm{C}$ and the supernatant was then stored in sterile vials at $-70^{\circ} \mathrm{C}$ until use for polymerase chain reaction (PCR) templates.

\section{Polymerase chain reaction (PCR)}

To confirm the existence of the cagA gene, the PCR was performed using specific primers. The PCR was performed in a DNA thermal cycler (Bio-Rad, USA) in a volume of $25 \mu$ l. The PCR program consisted of an initial denaturation step at $94{ }^{\circ} \mathrm{C}$ for $4 \mathrm{~min}, 35 \times 94{ }^{\circ} \mathrm{C}$ for $30 \mathrm{~s}$, annealing at $60{ }^{\circ} \mathrm{C}$ for $30 \mathrm{~s}$, and extension at $72{ }^{\circ} \mathrm{C}$ for $20 \mathrm{~s}$. No template control was used as a negative control. Finally, PCR products were sequenced (Macrogen, South Korea).

\section{CPP and antisense design}

The CPP used in this study consisted of 13 amino acids, mainly arginine with a guanidine group to bind membranic carboxylic, sulfate, and phosphate groups with negative charges to facilitate peptide entry (RLRRKRRKRRKRRKRK). The peptides were designed with peptide design software including APD3 [29], Cell PPD [30], CPP pred [31], and CPP site 2.0 [32].

After predicting the mRNA secondary structure using $\mathrm{m}$ FOLD server [33], 13 nucleotide target sequences or antisenses (TACTGATTACTTTGGT; Figure 1) were chosen as a complementary of a specific target region of cagA gene to construct the PNA compound. The cell-penetrating peptidepeptide nucleic acid (CPP-PNA) was synthesized by Panagene company (Daejeon, South Korea). 
Table I. The sequence, product size, and melting temperature of the primers used in this study

\begin{tabular}{|c|c|c|c|c|}
\hline Name & Primer sequence & Amplicon (bp) & $\operatorname{Tm}\left({ }^{\circ} \mathrm{C}\right)$ & Reference \\
\hline \multirow[t]{2}{*}{ cagA } & F-5'-CAATGGTGGTCCTGGAGCTA-3' & \multirow[t]{2}{*}{140} & \multirow[t]{2}{*}{60} & \multirow[t]{2}{*}{ This study } \\
\hline & R-5'-ССТTTCTСАССАССТGСТА -3' & & & \\
\hline \multirow[t]{2}{*}{ 16srRNA } & F-5'-CTCATTGCGAAGGCGACCT-3' & \multirow[t]{2}{*}{74} & \multirow[t]{2}{*}{60} & \multirow[t]{2}{*}{ This study } \\
\hline & R-5'-TCTAATCCTGTTTGCTCCCCA-3' & & & \\
\hline
\end{tabular}

Note: F: forward; R: reverse.

Figure 1. The target region studied as the secondary structure of the cagA gene

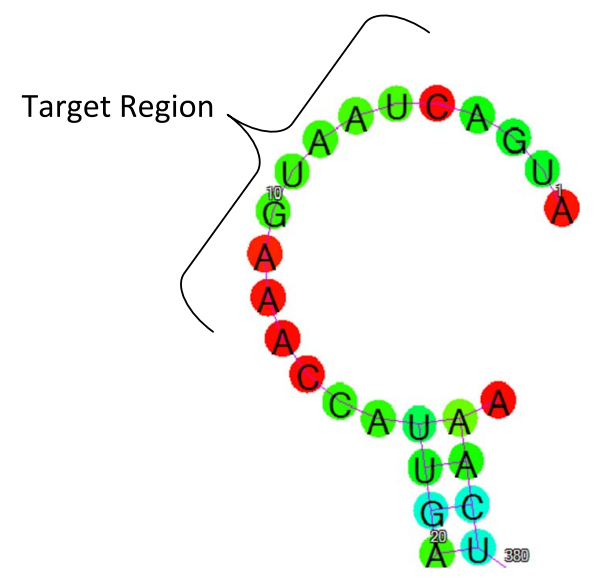

\section{Minimum inhibitory concentrations (MICs)}

The MIC of the CPP-PNA against H. pylori was determined according to the Clinical and Laboratory Standards Institute (CLSI) guidelines [34]. The MIC was recorded as the lowest concentration where no turbidity was observed in the tubes. A concentration of $32 \mu \mathrm{M}$ was prepared according to the company's protocol.

An amount of $50 \mu \mathrm{l}$ of Brucella broth was dispensed in each well and the serial dilution was prepared starting with $50 \mu \mathrm{l}$ of CPP-PNA with the concentration of $32 \mu \mathrm{M}$. An amount of $10 \mu \mathrm{l}$ of $0.5 \mathrm{MacFarland}$ was then added to each well. Brucella broth medium and the CPP-PNA were used as negative control and Brucella broth medium and the bacterium were used as a positive control. The final volume of each well was $100 \mu \mathrm{l}$.

The plate was incubated at $37^{\circ} \mathrm{C}$ under microaerophilic conditions. The MIC result was determined after $18 \mathrm{~h}$. The MICs were repeated at least twice.

\section{Log reduction assay}

H. pylori ATCC 43504 was diluted to $\sim 105 \mathrm{CFU} / \mathrm{ml}$ in logarithmic growth phase and incubated with 4 and $8 \mu \mathrm{M}$ of the CPP-PNA (in triplicates) at $37{ }^{\circ} \mathrm{C}$ for $24 \mathrm{~h}$. Samples were collected at 0,8 , and $24 \mathrm{~h}$, serially diluted, and plated onto Columbia agar plates. Plates were then incubated at $37^{\circ} \mathrm{C}$ for $24 \mathrm{~h}$ before CFUs were determined.

\section{Measuring cagA expression in CPP-PNA-treated H. pylori}

The effect of CPP-PNA with concentrations of 1, 2, 4, and $8 \mu \mathrm{M}$ was assessed on cagA expression level at $0,2,4$, and $6 \mathrm{~h}$ via real-time PCR method. The sub-MIC concentration was used for RNA extraction. An amount of $100 \mu$ of treated and untreated bacteria was then pelleted by centrifugation at $2,500 \times g$ for $15 \mathrm{~min}$. Total RNA was isolated using the QIAGEN RNeasy Mini kit (Qiagen, Germany). The extracted RNA was analyzed using a Nanodrop ND1000 and running on a denaturing $1.5 \%$ TAE-agarose gel ( $80 \mathrm{~V}$ for $1 \mathrm{~h}$ ) to assess RNA concentration, quality, and integrity. The RNA was DNase-treated with Promega RNase-free DNase (at $37^{\circ} \mathrm{C}$ for $1 \mathrm{~h})$. Next, RNA was precipitated with 1 volume of isopropanol and 0.1 volume of $3 \mathrm{M} \mathrm{NaOAc}(\mathrm{pH} 4.6)$. The suspension was incubated on ice for $20 \mathrm{~min}$ and centrifuged at high speed for $15 \mathrm{~min}$ at $4{ }^{\circ} \mathrm{C}$. The RNA pellet was dried and resuspended with RNase-free MilliQ $\mathrm{H}_{2} \mathrm{O}$. According to the manufacturer's instructions, $500 \mathrm{ng}-1 \mu \mathrm{g}$ RNA was converted into cDNA using AccuPower CycleScript RT PreMix (Bioneer, Korea). Finally, quantitative real-time PCR was performed in a Rotor-Gene thermal cycler (Corbett 6000, Australia) using the SYBR Green method (AccuPower Green Star qPCR Master Mix, Bioneer, Korea). A total volume of $20 \mu \mathrm{l}$ reaction consisting of $2 \mu \mathrm{l}$ of $\mathrm{cDNA}, 12.5 \mu \mathrm{l}$ of SYBR Green master mix, $4.5 \mu \mathrm{l}$ of nuclease-free water, and $1 \mu \mathrm{l}$ of each primer $(5 \mathrm{pmol})$ was run according to the following program: an initial activation step at $94{ }^{\circ} \mathrm{C}$ for $4 \mathrm{~min}$, 35 cycles of denaturation at $94{ }^{\circ} \mathrm{C}$ for $30 \mathrm{~s}$, annealing at $60{ }^{\circ} \mathrm{C}$ for $30 \mathrm{~s}$, and extension at $72{ }^{\circ} \mathrm{C}$ for $20 \mathrm{~s} 16 \mathrm{~s} r R N A$ was used as an internal control to normalize target gene expression measurements. Real-time PCR results were analyzed using the 2(-Delta Delta C(T)) method [35].

\section{Cell culture infection assay}

To assess the ability of CPP-PNA in vitro, cell culture infection assay in human HT29 cell line was performed. HT29 cells were grown in T75 flasks containing RPMI medium, 20\% fetal bovine serum, $1 \%$ sodium pyruvate, $1 \%$ non-essential amino acids, and were then incubated at $37^{\circ} \mathrm{C}$.

The concentration of $2 \times 10^{7} \mathrm{CFU} / \mathrm{ml}$ of bacteria (multiplicities of infection $\sim 1-10$ ) was inoculated to each well 
containing HT29 cells and concentrations of $1,2,4$, and $8 \mu \mathrm{M}$ of CPP-PNA were added to the infected cells and incubated for $4 \mathrm{~h}$ at $37{ }^{\circ} \mathrm{C}$ with $5 \% \mathrm{CO}_{2}$.

After washing steps, the total RNA was extracted and the expression of cagA was evaluated by real-time PCR.

\section{RESULTS}

\section{Bacterial log reduction determination}

Figures 2 and 3 illustrate the average number of viable bacteria after treatment and the corresponding log reduction associated with CPP-PNA (relative to the control), respectively. The results showed 2 and $3 \log$ reduction in bacterial count at 4 and $8 \mu \mathrm{M}$ of CPP-PNA after $18 \mathrm{~h}$, and 1 and $2 \log$ reduction in bacterial count at 4 and $8 \mu \mathrm{M}$ of CPP-PNA after 8, respectively. Overall, a concentrationdependent bacterial reduction was observed. This reduction in the number of bacteria may be due to the peptide portion of the CPP-PNA, which causes damage to the bacterial membrane.

Figure 2. Bacterial log reduction in the presence of $4 \mu \mathrm{M}$ of CPP-PNA at 0,8 , and $18 \mathrm{~h}$. Bacterial colony counts were analyzed to assess bacterial survival $(p<0.001)$

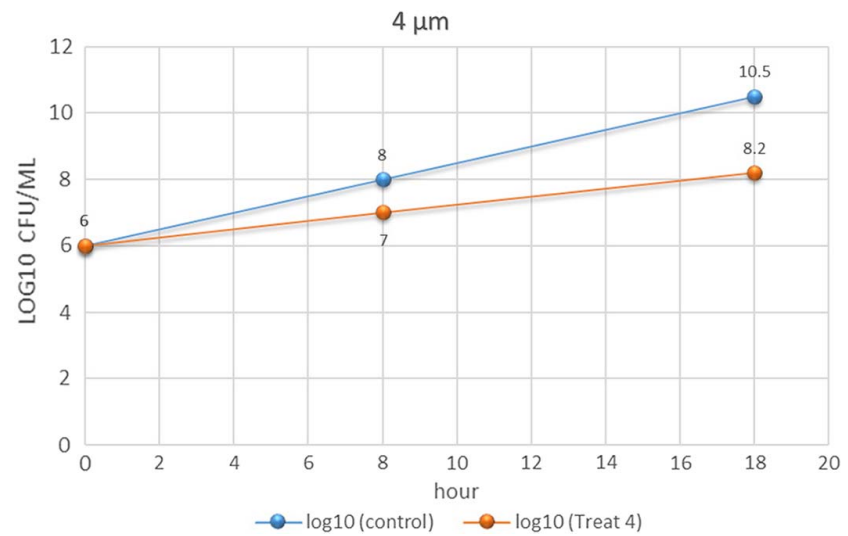

Figure 3. Bacterial log reduction in the presence of $8 \mu \mathrm{M}$ of CPPPNA at 0,8 , and $18 \mathrm{~h}$. Bacterial colony counts were analyzed to assess bacterial survival $(p<0.001)$

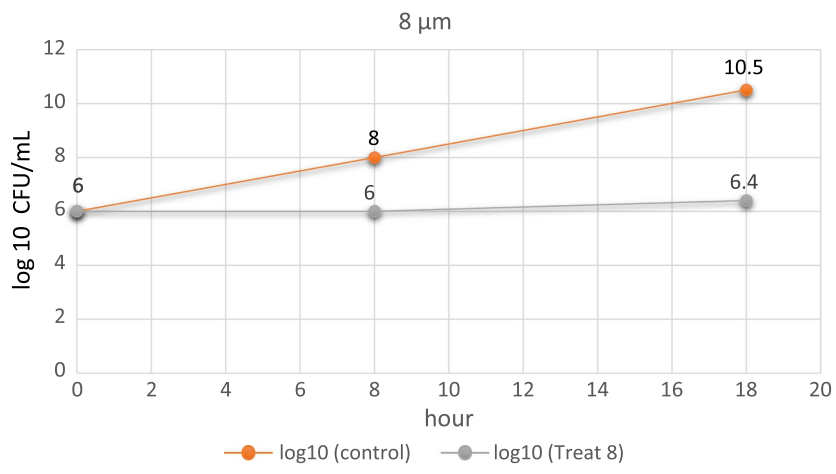

\section{CPP-PNA inhibits cagA gene expression}

In the presence of the CPP-PNA, cagA gene expression reduced. The results show that the treatment of $H$. pylori with CPP-PNA at different time intervals influences cagA gene expression. cagA gene expression was lower in the concentration of $8 \mu \mathrm{M}$ of CPP-PNA, compared to the concentrations of 1,2 , and $4 \mu \mathrm{M}$ after $6 \mathrm{~h}$ (Figures 4-7).

Figure 4. Gene expression analysis by real-time PCR at concentration of $1 \mu \mathrm{M}$ of CPP-PNA at $0,2,4$, and $6 \mathrm{~h}$. Relative expression is normalized with housekeeping gene 16srRNA ( $p<0.001$ by Bonferroni test)

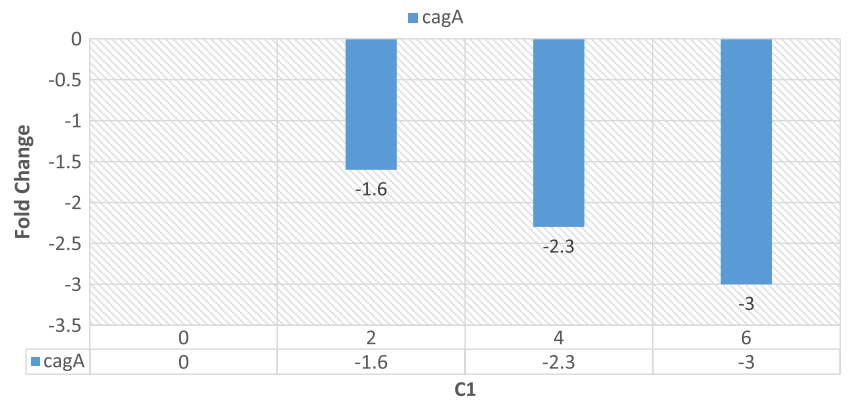

Figure 5. Gene expression analysis by real-time PCR at concentration of $2 \mu \mathrm{M}$ of CPP-PNA at $0,2,4$, and $6 \mathrm{~h}$. Relative expression is normalized with housekeeping gene 16srRNA ( $p<0.001$ by Bonferroni test)

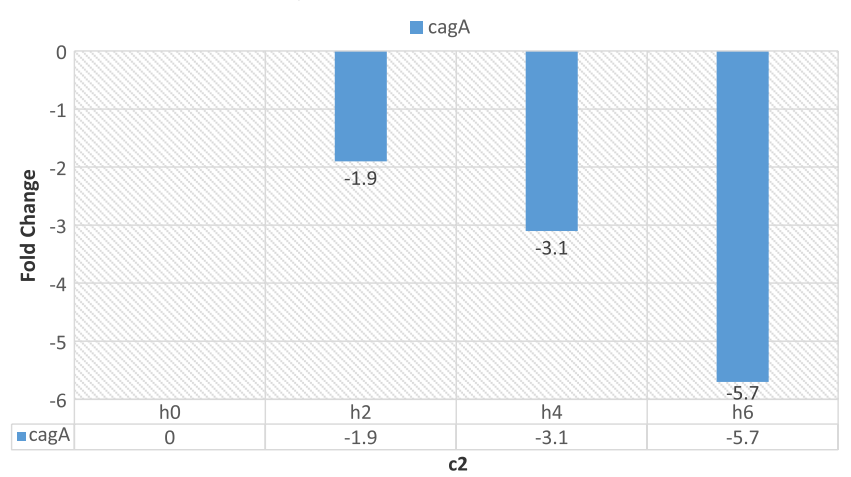

Figure 6. Gene expression analysis by real-time PCR at concentration of $4 \mu \mathrm{M}$ of CPP-PNA at $0,2,4$, and $6 \mathrm{~h}$. Relative expression is normalized with housekeeping gene 16srRNA ( $p<0.005$ by Bonferroni test)

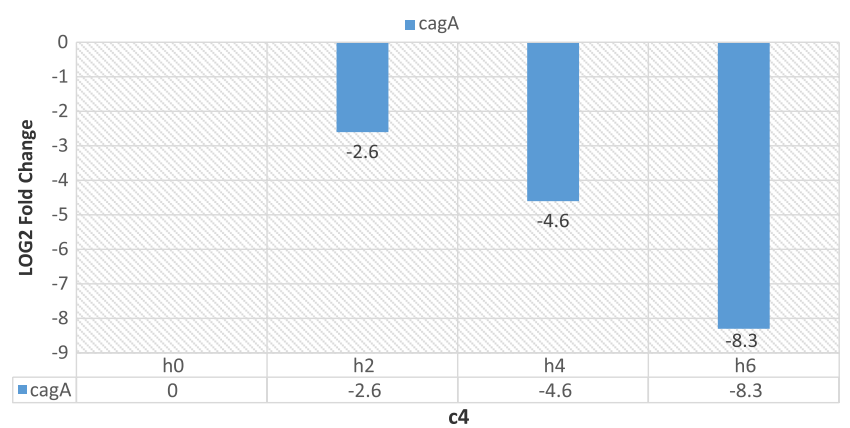


Figure 7. Gene expression analysis by real-time PCR at concentration of $8 \mu \mathrm{M}$ of CPP-PNA at $0,2,4$, and $6 \mathrm{~h}$. Relative expression is normalized with housekeeping gene 16srRNA $(p<0.005$ by Bonferroni test)

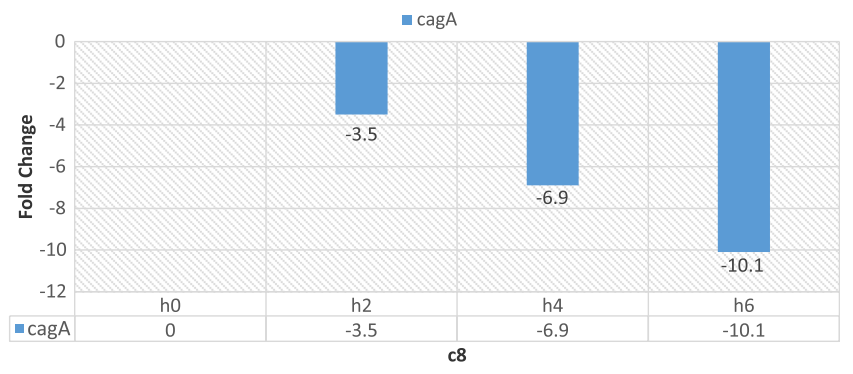

These results show that the CPP-PNA efficiency is directly linked with duration and concentration.

\section{CPP-PNA inhibits cagA gene expression in infected cell cultures}

The result of cell culture infection assay showed that CPP-PNA affects the cagA expression in human HT29 cell. At the concentration of $8 \mu \mathrm{M}$, we observed the highest decrease in cagA gene expression after $4 \mathrm{~h}$ compared to the concentrations of 1,2 , and $4 \mu \mathrm{M}$. After this time, about sevenfold of decrease in expression was observed (Figure 8).

\section{DISCUSSION}

The WHO categorized H. pylori as a group I carcinogen for gastric cancer in 1994 on the basis of observational studies [5].

Various and sporadic studies in Iran show the prevalence rate of $40 \%-80 \%$ for this bacterium among different populations [36-39]. In addition to high prevalence, antibiotic resistance in this bacterium is also rising similar to other bacteria [40]. Researchers today believe that antibiotics alone are not enough to cope with bacteria and that there is a pressing need for new compounds [41]. cag PAI is known to be a major contributor of H. Pylori pathogenecity [42]. CagA was described as the first bacterial oncogene [42]. In this study, the cagA gene, which is a sample of carcinogenic cytotoxins, was targeted [42]. Suppressing essential and

Figure 8. Gene expression analysis by real-time PCR in cell culture at concentration of $8 \mu \mathrm{M}$ of CPP-PNA after $4 \mathrm{~h}$. Relative expression is normalized with housekeeping gene 16srRNA ( $p<0.005$ by Bonferroni test)

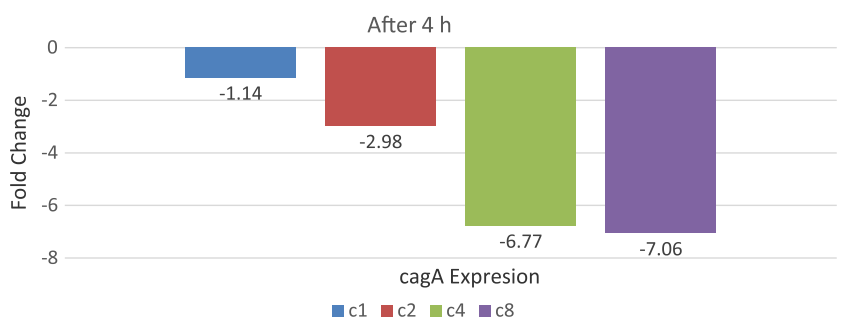

virulence genes, or inhibiting mRNA genes using antisense mechanisms, can be a new strategy to combat bacteria. The aim of this study was to investigate the effect of the CPP-PNA on the inhibition of $H$. pylori cagA expression. The results of this study showed at high concentrations of the CPP-PNA have a good effect on bacterial growth inhibition. Since the CPP-PNA in this study was designed against the pathogenic gene, and not the genes involved in bacterial survival, it can be concluded that the bacterial population is decreased owing to the peptide portion of CPP-PNA that in high amounts can damage the bacterial membrane, which can ultimately lead to bacterial death.

Similar results have been reported in the study of Abushahba et al. [25], in which they examined the effect of $\mathrm{CPP}$ on the effectiveness of antisense sequences against $\alpha$ subunit of RNA polymerase in Listeria monocytogenes. The results of their study showed that the CPP-PNA compounds rapidly kill L. monocytogenes within 20 min without disrupting the bacterial cell membrane. Moreover, rpoA gene silencing resulted in the suppression of its signaling as well as reducing the expression of other critical virulence genes (Listeriolysin $\mathrm{O}$ and two phospholipases plcA and $p l c \mathrm{~B}$ ) in a concentration-dependent manner [25].

Regarding the previous studies and the role of arginine in the transport of CPPs into bacteria and cells, CPP in this study was designed to consist mainly of this amino acid, and the results showed high efficiency of the designed peptide to deliver antisense sequences. The effect of different peptides including TAT, ANT, RXR, RFR, and KFF was investigated on inhibition of the target gene in Seleem et al.'s study on L. monocytogenes in vitro [25]. The results of their study showed that the peptide containing arginine and lysine is more efficient than other peptides. Various studies have shown that the use of positively charged peptides is more suitable for the transmission of antisense compounds [43, 44].

A significant decrease in cagA gene expression was observed in the presence of CPP-PNA. This reduction is associated with an increase in the concentration of the CPP-PNA. Therefore, cagA gene expression was significantly lower at the concentration of $8 \mu \mathrm{M}$ CPP-PNA compared to the concentrations of 1,2 , and $4 \mu \mathrm{M}$ at the same time intervals.

In a study by Seleem et al. on Salmonella enterica in 2012, various PNAs were used to inhibit rpoD, rpoA, engA, tsf, $k d t \mathrm{~A}$, and lig $\mathrm{A}$ genes. They reported that PNAs had a significant inhibitory effect on the target genes at different concentrations of $5,10,15$, and $20 \mu \mathrm{M}$, and this effect showed a direct relationship with increasing concentrations [45], which is consistent with this study.

In 2013, Rajasekaran et al. [46] reported the inhibitory effect of PNAs on Brucella suis growth in pure culture, and in infected murine macrophages, they reported that the most effective PNA in broth culture was that targeting polA at $12 \mu \mathrm{M}$. In contrast, in B. suis-infected macrophages, the most effective PNAs were those targeting asd and $d n a G$ at $30 \mu \mathrm{M}$; both of these PNAs had little inhibitory effect on B. suis in broth culture. The polA PNA that inhibited B. suis also 
inhibited the growth of B. melitensis $16 \mathrm{M}$ and B. abortus 2308 in culture media [46]. This study suggested the potential usefulness of antisense PNA constructs as novel therapeutic agents against intracellular Brucella.

In cell culture, the treatment of $H$. pylori with CPP-PNA affected the expression level of cagA gene after $4 \mathrm{~h}$. At the concentration of $8 \mu \mathrm{M}$, lowest cagA gene expression was observed after $4 \mathrm{~h}$ compared to the concentrations of 1,2 , and $4 \mu \mathrm{M}$. These results indicate the efficacy of these compounds in cell culture.

In a study conducted on S. enterica in 2012 by Muhammad A. Soofi and Mohamed N. Seleem, the effect of different CPP-PNA conjugates on cell culture was investigated and infected cells were incubated for $4 \mathrm{~h}$ with different PNAs. Consequently, they observed that these compounds resulted in inhibition of the expression of target genes and ultimately reduced the bacterial growth [45], which was consistent with the results of this study.

\section{CONCLUSIONS}

The results of this study indicate that CPP-antisense compounds are effective tools for inhibiting the target gene mRNA and can be used for various research, therapeutic and preventive purposes, but the safety, toxicity, and immunogenicity of these compounds should be thoroughly investigated. In general, the results of this study confirm the efficacy of these compounds as auxiliary compounds or in combination with other drugs for the treatment of infectious agents and genetic defects. Moreover, due to the considerable ability of these compounds in binding mRNA and target genes compared to DNA probes, it is possible to add fluorescent tags to the antisense sequence to identify pathogenic agents such as Mycobacterium tuberculosis in the sputum specimen, as well as to identify infectious agents in samples with a small amount such as food and water.

Acknowledgements: This study was financially supported by a research grant (no. 96-01-30-30536) for a MSc thesis in Iran University of Medical Sciences (Tehran, Iran), for which the authors are very grateful.

Conflict of Interest: The authors declare no competing interests.

\section{REFERENCES}

1. Parsonnet, J., Friedman, G. D., Vandersteen, D. P., Chang, Y., Vogelman, J. H., Orentreich, N., Sibley, R. K.: Helicobacter pylori infection and the risk of gastric carcinoma. N Engl J Med 325, 1127-1131 (1991).

2. Nomura, A., Stemmermann, G. N., Chyou, P.-H., Kato, I., Perez-Perez, G. I., Blaser, M. J.: Helicobacter pylori infection and gastric carcinoma among Japanese Americans in Hawaii. N Engl J Med 325, 1132-1136 (1991).
3. Forman, D., Newell, D., Fullerton, F., Yarnell, J., Stacey, A., Wald, N., Sitas, F.: Association between infection with Helicobacter pylori and risk of gastric cancer: Evidence from a prospective investigation. BMJ 302, 1302-1305 (1991).

4. Rezaeifar, A., Eskandari-Nasab, E., Moghadampour, M., Kharazi-Nejad, E., Hasani, S. S., Asadi-Saghandi, A., Hadadi-Fishani, M., Sepanjnia, A., Sadeghi-Kalani, B.: The association of interleukin-18 promoter polymorphisms and serum levels with duodenal ulcer, and their correlations with bacterial CagA and VacA virulence factors. Scand J Infect Dis 45, 584-592 (2013).

5. Uemura, N., Okamoto, S., Yamamoto, S., Matsumura, N., Yamaguchi, S., Yamakido, M., Taniyama, K., Sasaki, N., Schlemper, R. J.: Helicobacter pylori infection and the development of gastric cancer. N Engl J Med 345, 784-789 (2001).

6. Hsu, P.-I., Lai, K. H., Hsu, P. N., Lo, G. H., Yu, H. C., Chen, W. C., Tsay, F. W., Lin, H. C., Tseng, H. .H, Ger, L. P., Chen, H. C.: Helicobacter pylori infection and the risk of gastric malignancy. Am J Gastroenterol 102, 725-730 (2007).

7. Sokic-Milutinovic, A., Alempijevic, T., Milosavljevic, T.: Role of Helicobacter pylori infection in gastric carcinogenesis: Current knowledge and future directions. World J Gastroenterol 21, 11654 (2015).

8. Eskandari-Nasab, E., Sepanjnia, A., Moghadampour, M., Hadadi-Fishani, M., Rezaeifar, A., Asadi-Saghandi, A., Sadeghi-Kalani, B., Manshadi, M. D., Pourrajab, F., Pourmasoumi, H.: Circulating levels of interleukin (IL)-12 and IL-13 in Helicobacter pylori-infected patients, and their associations with bacterial CagA and VacA virulence factors. Scand J Infect Dis 45, 342-349 (2013).

9. Parkin, D. M.: The global health burden of infectionassociated cancers in the year 2002. Int J Cancer 118, 3030-3044 (2006).

10. Ou, Z., Xiong, L., Li, D. Y., Geng, L., Li, L., Chen, P., Yang, M., Zeng, Y., Zhou, Z., Xia, H., Gong, S.: Evaluation of a new fluorescence quantitative PCR test for diagnosing Helicobacter pylori infection in children. BMC Gastroenterol 13, 7 (2013).

11. Khedmat, H., Karbasi-Afshar, R., Agah, S., Taheri, S.: Helicobacter pylori infection in the general population: A Middle Eastern perspective. Caspian J Intern Med 4, 745 (2013).

12. Tokudome, S., Ghadimi, R., Suzuki, S., Hosono, A., Tanaka, T., Arakawa, K., Zhao, Y., Hattori, N., Agawa, H., Marumoto, M., Ando, R., Moore, M. A.: Helicobacter pylori infection appears the prime risk factor for stomach cancer. Int J Cancer 119, 2991-2991 (2006).

13. Hatakeyama, M.: Structure and function of Helicobacter pylori CagA, the first-identified bacterial protein involved in human cancer. Proc Jpn Acad B 93, 196-219 (2017).

14. Shiota, S., Suzuki, R., Yamaoka, Y.: The significance of virulence factors in Helicobacter pylori. J Dig Dis 14, 341-349 (2013).

15. Roesler, B. M., Rabelo-Gonçalves, E. M., Zeitune, J. M.: Virulence factors of Helicobacter pylori: A review. Clin Med Insights Gastroenterol 7, 9-17 (2014).

16. Maeda, S., Ogura, K., Yoshida, H., Kanai, F., Ikenoue, T., Kato, N., Shiratori, Y., Omata, M.: Major virulence factors, VacA and CagA, are commonly positive in Helicobacter pylori isolates in Japan. Gut 42, 338-343 (1998). 
17. Wroblewski, L. E., Peek, R. M., Wilson, K. T.: Helicobacter pylori and gastric cancer: Factors that modulate disease risk. Clin Microbiol Rev 23, 713-739 (2010).

18. Roesler, B. M., Rabelo-Gonçalves, E. M. A., Zeitune, J. M. R.: Helicobacter pylori and upper gastrointestinal diseases: A review. Health 6, 263 (2014).

19. Goh, S., Stach, J., Good, L.: Antisense effects of PNAs in bacteria. In Peptide Nucleic Acids. Humana Press, Totowa, NJ, 2014, pp. 223-236.

20. Nielsen, P. E., Brolin, C., Ghosal, A.: Peptide nucleic acid (PNA) antisense drug discovery from antibiotics to muscular dystrophy. Int J Mol Med 32, S35 (2013).

21. Valero, J., Shiraishi, T., de Mendoza, J., Nielsen, P. E.: Cellular antisense activity of PNA-oligo (bicycloguanidinium) conjugates forming self-assembled nanoaggregates. Chembiochem 16, 1593-1600 (2015).

22. Cerqueira, L., Azevedo, N. F., Almeida, C., Jardim, T., Keevil, C. W., Vieira, M. J.: DNA mimics for the rapid identification of microorganisms by fluorescence in situ hybridization (FISH). Int J Mol Sci 9, 1944-1960 (2008).

23. Rigby, S., Procop, G. W., Haase, G., Wilson, D., Hall, G., Kurtzman, C., Oliveira, K., Von Oy, S., Hyldig-Nielsen, J. J., Coull, J., Stender, H.: Fluorescence in situ hybridization with peptide nucleic acid probes for rapid identification of Candida albicans directly from blood culture bottles. J Clin Microbiol 40, 2182-2186 (2002).

24. Zhao, X.-L., Chen, B.-C., Han, J.-C., Wei, L., Pan, X.-B.: Delivery of cell-penetrating peptide-peptide nucleic acid conjugates by assembly on an oligonucleotide scaffold. Sci Rep 5, 17640 (2015).

25. Abushahba, M. F., Mohammad, H., Thangamani, S., Hussein, A. A., Seleem, M. N.: Impact of different cell penetrating peptides on the efficacy of antisense therapeutics for targeting intracellular pathogens. Sci Rep 6, 20832 (2016).

26. Rychlik, W.: OLIGO 7 primer analysis software. In PCR Primer Design. Humana Press, 2007, pp. 35-59.

27. Untergasser, A., Cutcutache, I., Koressaar, T., Ye, J., Faircloth, B. C., Remm, M., Rozen, S. G.: Primer3 - New capabilities and interfaces. Nucleic Acids Res 40, e115-e115 (2012).

28. Falsafi, T., Favaedi, R., Mahjoub, F., Najafi, M.: Application of stool-PCR test for diagnosis of Helicobacter pylori infection in children. World J Gastroenterol 15, 484 (2009).

29. Wang, G., Li, X., Wang, Z.: APD3: The antimicrobial peptide database as a tool for research and education. Nucleic Acids Res 44, D1087-D1093 (2015).

30. Gautam, A., Chaudhary, K., Kumar, R., Sharma, A., Kapoor, P., Tyagi, A., Raghava, G. P.: In silico approaches for designing highly effective cell penetrating peptides. J Transl Med 11, 74 (2013).

31. Holton, T. A., Pollastri, G., Shields, D. C., Mooney, C.: CPPpred: Prediction of cell penetrating peptides. Bioinformatics 29, 3094-3096 (2013).

32. Agrawal, P., Bhalla, S., Usmani, S. S., Singh, S., Chaudhary, K., Raghava, G. P., Gautam, A.: CPPsite 2.0: A repository of experimentally validated cell-penetrating peptides. Nucleic Acids Res 44, D1098-D1103 (2015).

33. Zuker, M.: Mfold web server for nucleic acid folding and hybridization prediction. Nucleic acids research 31, 3406-3415 (2003).

34. Clinical and Laboratory Standards Institute [CLSI]: Performance Standards for Antimicrobial Susceptibility Testing. CLSI, Wayne, PA, 2011.

35. Livak, K. J., Schmittgen, T. D.: Analysis of relative gene expression data using real-time quantitative PCR and the 2- $\Delta \Delta$ CT method. Methods 25, 402-408 (2001).

36. Nouraie, M., Latifi-Navid, S., Rezvan, H., Radmard, A. R., Maghsudlu, M., Zaer-Rezaii, H., Amini, S., Siavoshi, F., Malekzadeh, R.: Childhood hygienic practice and family education status determine the prevalence of Helicobacter pylori infection in Iran. Helicobacter 14, 40-46 (2009).

37. Fallahi, G.-H., Maleknejad, S.: Helicobacter pylori culture and antimicrobial resistance in Iran. Indian J Pediatr 74, 127 (2007).

38. Hashemi, M. R., Rahnavardi, M., Bikdeli, B., Zahedani, M. D. H. pylori infection among 1000 southern Iranian dyspeptic patients. World J Gastroenterol 12, 5479 (2006).

39. Malekzadeh, R., Derakhshan, M. H., Malekzadeh, Z.: Gastric cancer in Iran: Epidemiology and risk factors. Arch Iran Med 12, 576-583 (2009).

40. Zagari, R. M., Rabitti, S., Eusebi, L. H., Bazzoli, F.: Treatment of Helicobacter pylori infection: A clinical practice update. Eur J Clin Investig 48, e12857 (2018).

41. Roca, I., Akova, M., Baquero, F., Carlet, J., Cavaleri, M., Coenen, S., Cohen, J., Findlay, D., Gyssens, I., Heuer, O. E., Kahlmeter, G., Kruse, H., Laxminarayan, R., Liébana, E., López-Cerero, L., MacGowan, A., Martins, M., RodríguezBaño, J., Rolain, J. M., Segovia, C., Sigauque, B., Tacconelli, E., Wellington, E., Vila, J.: The global threat of antimicrobial resistance: Science for intervention. New Microbes New Infect 6, 22-29 (2015).

42. Backert, S., Blaser, M. J.: The role of CagA in the gastric biology of Helicobacter pylori. Cancer Res 76, 4028-4031 (2016).

43. Trabulo, S., Cardoso, A. L., Mano, M., De Lima, M. C. P.: Cellpenetrating peptides - Mechanisms of cellular uptake and generation of delivery systems. Pharmaceuticals 3, 961-993 (2010).

44. Kalafatovic, D., Giralt, E.: Cell-penetrating peptides: Design strategies beyond primary structure and amphipathicity. Molecules 22, 1929 (2017).

45. Soofi, M. A., Seleem, M. N.: Targeting essential genes in Salmonella enterica Serovar Typhimurium with antisense peptide nucleic acid. Antimicrob Agents Chemother 56, 64076409 (2012).

46. Rajasekaran, P., Alexander, J. C., Seleem, M. N., Jain, N., Sriranganathan, N., Wattam, A. R., Setubal, J. C., Boyle, S. M.: Peptide nucleic acids inhibit growth of Brucella suis in pure culture and in infected murine macrophages. Int Journal Antimicrob Agents 41, 358-362 (2013). 